\title{
The Application of Biofertilizer on Growth And Yield of Melon Varieties (Cucumis Melo L.)
}

\author{
Safwandi' ${ }^{1}$ Fadli Hanani2 ${ }^{2}$ Muhammad Yusuf N², Jamidi², Hafifah ${ }^{2}$ Ismadi2 $^{*}$ \\ ${ }_{1}^{1}$ Postgraduate Student, Department of Agroecotechnology, Faculty of Agriculture, Universitas Malikussaleh, \\ Reuleut Campus, Muara Batu, Aceh Utara 24355, Indonesia \\ ${ }^{2}$ Department of Agroecotechnology, Faculty of Agriculture, Universitas Malikussaleh, Aceh Utara, Indonesia \\ Reuleut Campus, Muara Batu, Aceh Utara 24355, Indonesia \\ *Corresponding author: ismadi@unimal.ac.id
}

\begin{abstract}
ARTICLE HISTORY
Received : 12 September 2021

Revised : 25 September 2021

Accepted : 10 October 2021
\end{abstract}

\section{KEYWORDS}

Melon;

Growth;

Biofertilizer;

Varieties;

\begin{abstract}
Melon (Cucumis melo L.) is one of potential horticultural crop in Indonesia. Unfortunately, melon production is currently unable to meet national demand. The objective of this study was to investigate the effect of biofertilizer, varieties and interaction between the dose of biofertilizer and varieties on the growth and yield of melons. The study was conducted in January-April 2021 at Paloh Lada Village, Dewantara District and the Laboratory of Agriculture Faculty, Universitas Malikussaleh. These experiments were arranged in a Factorial Randomized Block Design (RBD) with two factors. The first factor was biofertilizer (P) consisting of 4 levels: P0 (0 ml/L), P1 (5 $\mathrm{ml} / \mathrm{L}), \mathrm{P} 2(10 \mathrm{ml} / \mathrm{L})$ and P3 (15 ml/L) and the second factor was melon varieties (V): V1 (F1 Pertiwi Anvi) and V2 (F1 Action 88). There was 8 treatment combinations with 3 replications, resulted in 24 experimental units. The interaction between biofertilizers and varieties gave significant effect on the growth and yield of melon, while the interactions between bio fertilizer did not differ on all variables observed. The application of biological fertilizer $10 \mathrm{ml} / \mathrm{L}$ on V1 variety (F1 Pertiwi Anvi) is recommendable. There was an interaction between of biological

fertilizers and melon varieties on the total dissolved solids (Brix \%).
\end{abstract}

This is an open-access article under the CC-BY-SA license.

\section{INTRODUCTION}

Melon (Cucumis melo L.) is a potential horticultural crop belongs to family Cucurbitae. This fruit is popular for its sweet taste and juicy flesh. Higher demand on this commodity can improve farmer's income, compared to demand on other horticultural crops (Makful et al., 2017). The nutrients in $100 \mathrm{~g}$ melons are protein and calcium 6 mgg, thiamine $0.045 \mathrm{mg}$, vitamin A 5.706,5 IU, vitamin C $74.7 \mathrm{mg}$, vitamin B2 $0.065 \mathrm{mg}$, carbohydrate $6 \mathrm{mg}$, niacin $1 \mathrm{mg}$, riboflavin $0.065 \mathrm{mg}$, zinc $0.4 \mathrm{mg}$, nicotiamide $0,5 \mathrm{mg}$, water $93 \mathrm{ml}$, fibre $0.4 \mathrm{~g}$ and 23 calories (Departemen Pertanian, 2012).

National production of melons reached up to 138,177 tons (BPS, 2020), harvested from land 5,879 ha (Statistik Pertanian, 2018) with harvesting average by 23.5 tons/ha. This production is still low and unable to meet the national demand $(0.51 \mathrm{~kg} /$ year$)$. Recently, melon production in Aceh reached up to 182 tons in 2020 (BPS, 2020) from land 26 ha (Statistik Pertanian, 2018). In 2019, population in Aceh was 5,371,532 (BPS Provinsi Aceh, 2020) with their consumption level $33 \mathrm{~g} /$ capita per year, which is considered low.

Unawareness of inorganic fertilizer application leads to soil degradation and the decrease of biological properties. The use of these synthetic fertilizers has caused low diversity of microorganism in the soil, causing lower soil productivity and quality. Lower soil productivity and quality contributed to lower quality and quantity of crops (Sulastri et al., 2018). There are several efforts can be applied to improve melon yield, such as the use of biofertilizer and superior varieties. The use of fertilizer, soil aeration, temperature and variety determine the quality and quantity of melon production (Tang et al., 2012).

The application of biofertilizer is expected to improve soil fertility and to increase the growth and yield of crops significantly (Simamarta, 2011). Microbes such as Azospirilliun, Azotobacter, phosphate solubilizing bacteria, cellulose degrading microbes and also plant growth regulator IAA and cellulose enzyme from biofertilizer provides important nutrient in the soil by decomposing organic matter (Lusmaniar et al., 2011; Simanungkalit et al., 2011). Hamzah et al. (2011) found that the application of biofertilizer Agrobost has increased maize height, leaf number, stem diameter, corncob weight/plot, corncob weight per sample and corncob length.

The use of superior varieties also contributes to an increase of melon production. Planting superior melon varieties on the appropriate soil condition has improved the melon production due to proper interaction between 
plant genotype and its environment (Makful et al., 2017). Deus et al. (2015) reported that melon var. Action 434 was the best for its fruit weight and thick flesh, var. Aromis was the best for its vitamin $\mathrm{C}$ level and water content and var. Glamour was the best for its flesh color and firmness.

\section{MATERIALS AND METHODS}

The research was conducted in Glee Madat, Paloh Lada Village, Dewantara District, Aceh Utara Regency and at Agricultural Science Laboratory, Faculty of Agriculture, Universitas Malikussaleh, from June - September 2021.

The materials used in this research were melon seed var. F1 Pertiwi Anvi, F1 Action 88, biofertilizer Agrobost, cow manure, inorganic fertilizer, polybags, label papers and pesticides. Equipments used were hoe, machete, knife, handsprayer $3 \mathrm{~L}$, sprayer $15 \mathrm{~L}$, plastic mulch, hand seeder, mulch hole burner, refractometer, CCM (Cholorophyl Content Meter), ruler, measuring tape, caliper, scissors,. raffia rope, masking tape, fork, watering can, bamboo stakes, camera and stationery.

Randomized Block Design (RBD) Factorial was employed in this research with 2 factors observed: liquid organic fertilizer (P) with 4 different doses: control (P0), 5 $\mathrm{ml} / \mathrm{L}$ (P1), $10 \mathrm{ml} / \mathrm{L} \mathrm{(P2)} \mathrm{and} 15 \mathrm{ml} / \mathrm{L}$ (P3). The second variable was melon varieties (V), F1 Pertiwi Anvi (V1) and F1 Action 88 (V2). There were 8 treatments with 3 replications, resulted in 24 experimental units.

Collected data were statistically analyzed using F-Test, where significant data existed were separated using Duncan's Multiple Range Test (DMRT) at probability 5\%. Plant height, stem diameter, leaf chlorophyll content, leaf width, fruit weight per plant and per plot, fruit diameter, fruit length, flesh thickness and total dissolved solids (Brix $\%$ ) were observed in these experiments.

\section{$2.1 \quad$ Field Trial}

Weeding is a necessary practice before land use to avoid weeds competing with crops. The land has been loosen and the beds $(360 \mathrm{~cm} \times 100 \mathrm{~cm})$ were built with a drainage $(40 \mathrm{~cm} \times 80 \mathrm{~cm})$ between them. Mulches were applied and planting holes were prepared with fertilizers applied on them before planting. The seeds were soaked in a glass of hot water for 5 hours to destroy seed-borne pathogens. Then, the seeds were placed on moistened towel and covered it for 24 hours before sowing the germinated seeds into fertilized soils $(3: 1)$ prepared in polybags $(10 \mathrm{~cm} \times 15 \mathrm{~cm})$. The 12-day-old seeds with $3-4$ leaves were ready to replanting.

Biofertilizer was mixed with water $1000 \mathrm{ml}$ and applied into the planting holes and 25 plants. The biofertilizers needed to be applied 5 times: 1 week before planting, 10, 20, 30, and 40 DAP. The axillary buds in the axil 1-8 were eliminated and the buds in the axil 9-13 of leaf were left to develop to form the shoots. This activity was repeated until the $30^{\text {th }}$ leaf for the apical meristem to be cut.

The melons were watered $(1000 \mathrm{ml} /$ plant $)$ twice a day. Plant thinning was applied to replace abnormal and undeveloped plants, where the thinning was performed 310 DAP. The attack of Pseudoperonospora cubensis, which causes downy mildew has been controlled with foliar contact fungicide contained Propineb. Foliage pests such as Spodoptera sp., leaf miner and fruit fly Dacus $s p$. were controlled using insecticide methomyl.

Melons were harvested 5 days before its harvesting time (usually at 60 DAP). Harvest readiness is indicated by stalk splitting, dull skin and the rind is creamy yellow and becomes smooth and waxy

\section{RESULTS AND DISCUSSIONS \\ 3.1. Results}

\subsubsection{Plant Height and Stem Diameter}

The results showed that biofertilizer doses and significantly increased the plant height at 1, 2, 3 and 4 weeks after planting (WAP). The application of $15 \mathrm{ml} / \mathrm{L}$ biofertilizer indicated the highest result and melon var. F1 Pertiwi Anvi exhibited the best result compared to var. F1 Action 88 in all variables observed. Stem diameters were increased at 2, 3 and 4 WAP and the application on 2 melon varieties did gave significant effect in each observation. The highest diameter was found in melon var. F1 Action 88 at 4 WAP with the application of $15 \mathrm{ml} / \mathrm{L}$ biofertilizer (Table 1).

Table 1. Application of biofertilizer on melon varieties, plant height an stem diameter

\begin{tabular}{|c|c|c|c|c|c|c|c|c|}
\hline \multirow{2}{*}{ Treatment } & \multicolumn{4}{|c|}{ Plant height (cm) } & \multicolumn{4}{|c|}{ Stem diameter $(\mathrm{cm})$} \\
\hline & 1 WAP & 2 WAP & 3 WAP & 4 WAP & $1 \mathrm{WAP}$ & 2 WAP & 3 WAP & 4 WAP \\
\hline \multicolumn{9}{|l|}{ Biofertilizer (P) } \\
\hline $\mathrm{P} 0(0 \mathrm{ml} / \mathrm{L})$ & $13.95 \mathrm{~b}$ & $24.36 \mathrm{~b}$ & 58.87 c & $143.25 \mathrm{c}$ & $0.447 \mathrm{a}$ & $0.549 \mathrm{~b}$ & $0.653 \mathrm{~b}$ & $0.722 \mathrm{c}$ \\
\hline P1 (5 ml/L) & $14.21 \mathrm{~b}$ & $25.63 \mathrm{a}$ & $69.25 \mathrm{~b}$ & $162.12 \mathrm{~b}$ & $0.458 \mathrm{a}$ & $0.581 \mathrm{a}$ & $0.748 \mathrm{a}$ & $0.801 \mathrm{~b}$ \\
\hline P2 (10 ml/L) & $14.86 \mathrm{a}$ & $26.52 \mathrm{a}$ & $71.70 \mathrm{a}$ & $166.12 \mathrm{a}$ & $0.462 \mathrm{a}$ & $0.591 \mathrm{a}$ & $0.759 \mathrm{a}$ & $0.829 \mathrm{a}$ \\
\hline P3 (15 ml/L) & $14.57 \mathrm{ab}$ & $26.56 \mathrm{a}$ & $71.95 \mathrm{a}$ & $166.33 \mathrm{a}$ & $0.455 \mathrm{a}$ & $0.606 \mathrm{a}$ & $0.757 \mathrm{a}$ & $0.833 \mathrm{a}$ \\
\hline \multicolumn{9}{|l|}{ Variety (V) } \\
\hline V1 (F1 Pertiwi Anvi) & $14.78 \mathrm{a}$ & $27.11 \mathrm{a}$ & $71.41 \mathrm{a}$ & $163.41 \mathrm{a}$ & $0.441 \mathrm{~b}$ & $0.545 \mathrm{~b}$ & $0.693 \mathrm{~b}$ & $0.760 \mathrm{~b}$ \\
\hline V2 (F1 Action 88) & $14.01 \mathrm{~b}$ & $24.42 \mathrm{~b}$ & $64.47 \mathrm{~b}$ & $155.60 \mathrm{~b}$ & $0.471 \mathrm{a}$ & $0.618 \mathrm{a}$ & $0.765 \mathrm{a}$ & $0.832 \mathrm{a}$ \\
\hline
\end{tabular}




\subsubsection{Chlorophyll Content and Leaf Width}

The results of ANOVA exhibited significant results of biofertilizer application on leaf chlorophyll content compared to control. The highest content, 43.24 CCI was demonstrated by melon plants var. F1 Pertiwi Anvi (42.25) treated with biofertilizer $15 \mathrm{ml} / \mathrm{L}$. However, this higher dose showed insignificant effect compared to lower doses.
For the leaf width, the application of $10 \mathrm{ml} / \mathrm{L}$ was the best. It exhibited the highest leaf width compared to control (354.896 $\mathrm{cm}^{2}$ ) but insignificant to other doses of biofertilizers. Also, melon variety F1 Action 88 possessed higher leaf width (389. $358 \mathrm{~cm}^{2}$ ) compared to var. F1 Pertiwi Anvi due to biofertilizer application (Table 2).

Table 2. Application of biofertilizer on melon varieties, leaf chlorophyll content and leaf width at 30 DAP

\begin{tabular}{lcc}
\hline \multicolumn{1}{r}{ Treatment } & Leaf Chlorophyll Content (CCI) & Leaf Width (cm $\left.{ }^{2}\right)$ \\
\cline { 1 - 2 } Biofertilizer (P) & $37.54 \mathrm{~b}$ & $294.735 \mathrm{~b}$ \\
P0 (0 ml/L) & $43.08 \mathrm{a}$ & $350.204 \mathrm{a}$ \\
P1 (5 ml/L) & $43.22 \mathrm{a}$ & $354.896 \mathrm{a}$ \\
P2 (10 ml/L) & $43.24 \mathrm{a}$ & $354.429 \mathrm{a}$ \\
P3 (15 ml/L) & & $287.774 \mathrm{~b}$ \\
Variety (V) & $42.25 \mathrm{a}$ & $389.358 \mathrm{a}$ \\
V1 (F1 Pertiwi Anvi) & $41.30 \mathrm{~b}$ & \\
V2 (F1 Action 88)
\end{tabular}

Mean values in the same columns followed by the same letters did not differ significantly as determined by Duncan's Multiple Range Test (DMRT) at 5\% probability level

\subsubsection{Fruit Weight per plant and per plot}

The application of biofertilizer possessed significant increase on fruit weight between 2 varieties. The application of $15 \mathrm{ml} / \mathrm{L}$ biofertilizer exhibited the highest fruit weight (both per plant and per plot) compared to control and the lowest dose of biofertilizer. Melon var. F1 Pertiwi Anvi indicated the best results on fruit weights (1142.02 g and 4568.08) compared to var. F1 Action 88. (Table 3).

Tabel 3. The application of biofertilizer on varieties and its fruit weight per plant and per plot

\begin{tabular}{lcc}
\hline \multicolumn{1}{c}{ Treatment } & Fruit Weight per Plant (g) & Fruit Weight per Plot (g) \\
\cline { 1 - 3 } Pupuk Hayati (P) & & $3561.67 \mathrm{c}$ \\
P0 (0 ml/L) & $890.41 \mathrm{c}$ & $4691.50 \mathrm{~b}$ \\
P1 (5 ml/L) & $1172.87 \mathrm{~b}$ & $4839.33 \mathrm{a}$ \\
P2 (10 ml/L) & $1209.83 \mathrm{a}$ & $4865.00 \mathrm{a}$ \\
P3 (15 ml/L) & $1216.25 \mathrm{a}$ & \\
\hline Varietas (V) & & $4568.08 \mathrm{a}$ \\
V1 (F1 Pertiwi Anvi) & $1142.02 \mathrm{a}$ & $4410.67 \mathrm{~b}$ \\
V2 (F1 Action 88) & $102.66 \mathrm{~b}$ & \\
\hline
\end{tabular}

\subsubsection{Fruit Diameter and Length (cm)}

The application of biofertilizer also demonstrated significant effect on fruit diameter and length. The application of $15 \mathrm{ml} / \mathrm{L}$ biofertilizer improved the fruit diameter and length $(39.69 \mathrm{~cm}$ and $12.85 \mathrm{~cm})$. For the melon varieties, var. F1 Pertiwi Anvi indicated the best results on its fruit diameter and length $(38.90 \mathrm{~cm}$ and $12.55 \mathrm{~cm}$ ) panjang buah per tanaman (Table 4). Table 4. Application of biofertilizer on melon varieties and its fruit diameter

\begin{tabular}{lcc}
\hline \multicolumn{1}{c}{ Treatment } & Fruit diameter $\mathbf{( c m )}$ & Fruit length (cm) \\
\cline { 1 - 3 } Pupuk Hayati (P) & $36,34 \mathrm{~d}$ & $11,07 \mathrm{c}$ \\
P0 (0 ml/L) & $38,81 \mathrm{c}$ & $12,57 \mathrm{~b}$ \\
P1 (5 ml/L) & $39,42 \mathrm{~b}$ & $12,77 \mathrm{a}$ \\
P2 (10 ml/L) & $39,69 \mathrm{a}$ & $12,85 \mathrm{a}$ \\
P3 (15 ml/l, & & $12,55 \mathrm{a}$ \\
\hline Varietas (V) & $38,90 \mathrm{a}$ & $12,08 \mathrm{~b}$ \\
V1 (F1 Pertiwi Anvi) & $38,23 \mathrm{~b}$ & \\
V2 (F1 Action 88) & & \\
\hline
\end{tabular}


3.1.5 Flesh Thickness and Total Dissolved Solids (Brix)

The results showed that the application of biofertilizer $15 \mathrm{ml} / \mathrm{L}$ has enhance the flesh thickness $(3.129 \mathrm{~cm})$ and the significant increase occurred in melon var. F1 Pertiwi Anvi compared to F1 Action 88. Also, the highest dose revealed the highest total dissolved solids (8.320\%) The highest doses demonstrated the highest results compared to control. However, it showed no differences compared to other lower doses (Table 5).

Table 5. The application of biofertilizer on varieties and its flesh thickness and total dissolved solids (Brix \%)

Treatment

Flesh thickness (cm)
Total Dissolved Solids (Brix \%)

\begin{tabular}{llc}
\hline Biofertilizer (P) & & $6.820 \mathrm{~b}$ \\
P0 (0 ml/L) & $2.697 \mathrm{c}$ & $8.251 \mathrm{a}$ \\
P1 (5 ml/L) & $3.020 \mathrm{c}$ & $8.310 \mathrm{a}$ \\
P2 $(10 \mathrm{ml} / \mathrm{L})$ & $3.104 \mathrm{a}$ & $8.320 \mathrm{a}$ \\
P3 $(15 \mathrm{ml} / \mathrm{L})$ & $3.129 \mathrm{a}$ & $8.175 \mathrm{a}$ \\
\hline Variety (V) & $3.043 \mathrm{a}$ & $7.675 \mathrm{~b}$ \\
V1 (F1 Pertiwi Anvi) & $2.922 \mathrm{~b}$ & \\
V2 (F1 Action 88) & \multicolumn{2}{c}{} \\
\hline Mean values in the same columns followed by the same letters did not differ significantly as determined by Duncan's Multiple Range Test (DMRT) at 5\% probability level
\end{tabular}

\subsection{Discussions}

Biofertilizer $15 \mathrm{ml} / \mathrm{L}$ performed better compared to other lower doses $(5 \mathrm{ml} / \mathrm{L}$ and $10 \mathrm{ml} / \mathrm{L})$ and control. It significantly improved plant height, stem diameter, chlorophyll content, leaf width, fruit weight, fruit diameter and length, flesh thickness and total dissolved solids. The existence of beneficial microbes, such as Azotobacter sp. and Azospirilium sp. was thought to be the cause of this positive result, by converting atmospheric nitrogen $\left(\mathrm{N}_{2}\right)$ into ammonium readily absorbable by plant roots. (Hamastuti, 2012). These soil microbes associate with plant roots to enhance the ability of plant absorbing important nutrients, including N element (Annisa \& Gustia, 2017; Husnaeni \& Setiawati, 2018). The research of Aritonang \& Surtinah (2018) also confirmed that treated melon plants exhibited better development compared to untreated ones. Lower development is linked to macro nutrient insufficiency. Surtinah (2017) found that the application of biofertilizer significantly increase the growth of sweet corn.

In this research, the application of biofertilizer Agrobost revealed the best performance in melon var. F1 Pertiwi Anvi compared to F1 Action 88. Variety F1 Pertiwi Anvi performed better in plant height and yield, while var. F1 Action 88 performed better in stem diameter and leaf width, where var. F1 Action 88 possesses wider leaf. However, var. Pertiwi Anvi demonstrated better results on harvest age and yield. Syukri (2015) informed that the application of biofertilizer Agrobost gave non-significant result on fruit diameter and length. This finding was related to genetic factors, where the genes responsible for fruit diameter and length were dominant. These genetic differences led to plant response to the environment, resulted in different plant growth and development (Sumartono, 2018). Deus et al. (2017) stated that genetic factor plays more important role in plant development compared to the application of biofertilizers. In this research, both varieties showed good ability in adapting to the environment. However, var. F1 Action 88 revealed better resistance of pest and disease attacks. This finding is in line with the research of Sumartono (2018), where he examined that wider leaf possessed by melon var. Silver Light was a result of better adaptation of the variety to the environment, triggering better growth and development.

\section{CONCLUSIONS}

1. The application of biofertilizer $15 \mathrm{ml} / \mathrm{L}$ significantly increased the plant height and stem diameter at all weeks observed compared to control. However, these results were insignificant compared to application of biofertilizer $10 \mathrm{ml} / \mathrm{L}$.

2. The application of biofertilizer $15 \mathrm{ml} / \mathrm{L}$ showed insignificant results between treatments. However, it is significantly increased compared to control.

3. The application of biofertilizer $15 \mathrm{ml} / \mathrm{L}$ had the best effect on fruit weight per plant and per plot compared to control and lower dose $5 \mathrm{ml} / \mathrm{L}$

4. The application of biofertilizer $15 \mathrm{ml} / \mathrm{L}$ increased the fruit length and diameter. Treated plants showed better results compared to untreated plants.

5. The application of biofertilizer performed better result on flesh thickness, eventhough the higher doses applied (10 and $15 \mathrm{ml} / \mathrm{L}$ ) showed non-significant results. For total dissolved solids, it was insignificant between treated plants. However, it gave significant results compared to control.

6. Melon var. F1 Pertiwi Anvi performed better with application of biofertilizer compared to var. F1 Action 88.

\section{REFERENCES}

Annisa, P., \& Gustia, H. (2018). Respon pertumbuhan dan produksi tanaman melon terhadap pemberian pupuk organik cair Tithonia diversifolia. Prosiding SEMNASTAN, 104-114.

Aritonang, S., \& Surtinah, S. (2018). Stimulasi Hasil Melon (Cucumis melo, 
L) Dengan Menggunakan Bioto Grow Gold (BGG). Fakultas Pertanian, Universitas Lancang Kuning, 15(1), 35-41.

BPS [Badan Pusat Statistik]. 2020. Produksi Tanaman Buah-buahan 1997-2020. https://www.bps.go.id/indicator. [Accessed on 10 June 2020].

BPS [Badan Pusat Statistik] Provinsi Aceh. 2019. Produksi Tanaman Sayuran Menurut Kabupaten/Kota dan Jenis Tanaman di Provinsi Aceh 2019. https://www.bps.go.id/indikator. [Accessed on 10 June 2020].

BPS [Badan Pusat Statistik] Provinsi Aceh. 2020. Jumlah Penduduk Provinsi Aceh Menurut Kabupaten/Kota Tahun 2017-2019. https://aceh.bps.go.id/statictable. [Accessed on 10 June 2020].

Departemen Pertanian. 2012. Melon, Buah Segar Berpotensi. http://www.deptan. go.id. [Accessed on 12 June 2020].

De Deus, A., Hariyono, K., \& Winarso, S. (2014). Penambahan Nutrisi Pada Tiga Varietas Melon Untuk Meningkatkan Hasil Dan Kualitas Buah [Nutrition in Addition to Improve the Tree Varieties of Melon and Fruit Quality]. Agritrop: Jurnal Ilmu-Ilmu Pertanian (Journal of Agricultural Science), 12(2).
Hamastuti, H., Dwi, E., Juliastuti, S., \& Hendrianie, N. (2012). Peran mikroorganisme Azotobacter chroococcum, Pseudomonas fluorescens, dan Aspergillus niger pada pembuatan kompos limbah sludge industri pengolahan susu. Jurnal Teknik Pomits, 1(1), 1-5.

Hamzah, S., Utami, S., \& Cholik, M. A. (2015). Pengaruh pupuk agrobost dan humagold terhadap pertumbuhan dan produksi jagung ketan (Zea mays ceratina). AGRIUM: Jurnal Ilmu Pertanian, 17(1).

Husnaeni, F., \& Setiawati, M. R. (2018). Pengaruh Pupuk Hayati dan Anorganik Terhadap Populasi Azotobacter, Kandungan N, dan Hasil Pakcoy Pada Sistem Nutrient Film Technique. Jurnal Biodjati, 3(1), 90-98.

Lusmaniar, L., Oksilia, O., \& Dewi, S. (2020). Pengaruh Pemberian Pupuk Hayati Agrobost Terhadap Pertumbuhan dan Hasil Tanaman Kacang Hijau (Vigna radiata L.). AGRONITAS, 2(1), 34-42.

Makful, H. Sahlan. (2017). Evaluasi dua calon varietas unggul melon di Sumatera Barat, Jawa Barat, dan Jawa Timur. Jurnal Hortikultura, 27(2), 185-194.

Syukri, S. (2015). Pengaruh Media Tanam dan Pupuk Hayati Agrobost Terhadap Pertumbuhan dan Hasil Tanaman Melon (Cucumis melo, L.) Dalam Polybag. Jurnal Penelitian Agrosamudra, 2(2), 19-28. 